\title{
The Wage of Sin is Orthodoxy: The Confessions of Saint Augustine in Bayle's Dictionnaire
}

\author{
RUTH E. WHELAN
}

la maniere la plus funeste d'attaquer une doctrine est celle de la tourner en ridicule

Pierre Bayle $^{1}$

THE CHALLENGE to ecclesiastical tradition, the derision visited on the church Fathers in the Age of Reason-as the case of Saint Augustine illustrates-owe much of their power to that Arsenal of the Enlightenment, Pierre Bayle. As early as 1727, Johannes Franciscus Buddeus, a German theologian and scholar, upbraids the liberal Protestant thinker Jean Barbeyrac for his imitation of Bayle's iconoclastic verve. ${ }^{2}$ In 1733, the French Catholic scholar, Charles Merlin, takes up the gauntlet in a work which specifically replies to the critique of Saint Augustine in the Commentaire philosophique and the Dictionnaire historique et critique. More polemical than erudite, Merlin's Refutation brings invective to the aid of inadequate argument in an attempt to deflect readers from that "empoisonneur infatigable des esprits," whose "médisance," "malignité," and "mépris insolent," towards Saint Augustine make him "le Docteur des impies de nos jours" and the friend of libertines. ${ }^{3}$ Now, the Refutation may be both obscurantist in its orthodoxy and ineffectual in its abusive rhetoric, nonetheless, it highlights-and somewhat prophetically-the existence of a

1 Pierre Bayle, "Sainte-Aldegonde," footnote G, Dictionaire historique et critique 4 vols. (Rotterdam: Michel Bohm, 1720). All references are to this edition; original spelling is respected throughout.

? Johannes Franciscus Buddeus, Isagoge historico-theologica ad theologiam universam cum appendice 3 vols (Lipsiae: Ex Officina Thomae Fritschii, 1727 ), I, 633 a.

3 Charles Merlin, Refutation des critiques de Monsieur Bayle sur saint Augustin (Paris: Rolin Fils, 1733), 75, 11, 14, 47, 93, 17. On Merlin cf. Pierre Rétat, Le 'Dictionnaire' de Bayle et la lutte philosophique au XVIIIe sizcle (Paris: Imprimerie Audin, 1971), 186-9o. 
group of kindred spirits who turn to Bayle for inspiration in the war on prejudice and superstition.

Undaunted by Buddeus' reproof, Barbeyrac published in 1728 a critical treatise on the moral theology of the church Fathers. The chapter devoted to Saint Augustine pillages the third part of the Commentaire philosophique and the by then famous passages of the Dictionnaire which consider some of the moral dilemmas proposed by the Doctor of Hippo.4 In $176_{5}$, the twelfth volume of the Encyclopédie appeared with an entry on the church Fathers written by the Chevalier de Jaucourt. The section on Saint Augustine summarizes the positions of Richard Simon, Bayle and Barbeyrac and rehearses, almost word for word, arguments from the Traité de la morale des peres de l'eglise and the earlier article on Augustine in the Dictionnaire.5 Referring to Bayle in his article "Augustin" (1770) in the Dictionnaire philosophique, Voltaire turns the account of Augustine's premature virility-given in the Confessions and repeated by Bayle-into a scabrous story, deleterious to the Saint's moral authority. ${ }^{6}$ These three highly articulate voices in a chorus of criticism and mockery directed against the Doctor of Hippo' seem to substantiate, then, the perception of Bayle's work as a slow poison designed to corrode the well-worn traditions of a beleaguered orthodoxy. With the wisdom of hindsight, however, the twentieth-century critic may choose to demur from this polemically inspired, mechanical conception of intellectual influence.

The annexation of Bayle to the cause of the Enlightenment depends, then, on the creative misconceptions of both his enemies and his self-proclaimed disciples. Voltaire's caricatural biography of Augustine, Barbeyrac and de Jaucourt's intellectual critique of the Saint's moral theology, biblical criticism and defense of civil and religious intolerance may seem to justify Merlin's

4 Jean Barbeyrac, Traité de la morale des peres de l'eglise (Amsterdam: Pierre de Coup, 1728), 281-315. For the moral dilemmas proposed by Augustine and Bayle's treatment of them see our The Anatomy of Superstition, A Study of the Historical Theory and Practice of Pierre Bayle (Ph.D. thesis: University of Dublin, Trinity College, 1984), 167-75

5 Encyclopédie ou Dictionnaire raisonné des sciences, des arts et des métiers, par une société de gens de lettres, 35 vols (Paris: Briasson, et al, 1751-1780), XII: $339 \mathrm{~b}-35^{\circ}$. On de Jaucourt, cf. Rétat, Bayle, 411-416 and Schwab, Richard N, "Un Encyclopédiste huguenot: le Chevalier de Jaucourt (un lien direct entre les érudits de la Dispersion et l'Encyclopédie)," Bulletin de la Société d'histoire du protestantisme français, avril-juin 1962): $45^{-75}$.

6 Voltaire, Oeuvres complètes, 70 vols. (Imprimerie de la société littéraire-typographique, ${ }_{17} 8_{5}-1789,38: 144-46$. The article is dated by H. T. Mason, Pierre Bayle and Voltaire (Oxford University Press, 1963), 48. For the story in question, see Confessions, II,3 and Bayle, "Augustin," footnote $B$.

7 Rétat (Bayle, passim) documents the critique of Saint Augustine in the eighteenth century. Pierre Courcelle Les Confessions de saint Augustin dans la tradition littéraire (Paris: Études Augustiniennes, 1963 ). 458-6o traces Bayle's influence on some eighteenth-century thinkers, notably Voltaire. 
early identification of a libertine complicity but, despite the textual references, the later positions are as much an interpretation as a repetition of the earlier thinker. In their campaign against ideological and political totalitarianism, the later writers - out of touch with Bayle's socio-historical context-generalize his evident disrespect towards the Doctor of Hippo and his arguments for toleration. Once read anachronistically, irony and indignation become subversive profanation. The purpose of this paper is, then, to restore as far as possible the intellectual and socio-historical context which inform the article "Augustin" in the Dictionnaire. Our analysis reveals not only the theological basis of Bayle's undeniable iconoclasm but also its genesis within the political experience of an oppressed minority and the ideological tensions of the Huguenot community in exile in Holland. As we shall see, the later generalization of the entry is not without foundation but the interpretation of Bayle as an Enlightened encyclopedist avant la lettre falsifies the ambivalence of his attitude to a theologian he simultaneously admires and seeks to ridicule.

The short biographical entry on Saint Augustine in the Dictionnaire is deliberately incomplete in its concentration on the Saint's youth, conversion, and early career. Bayle draws his information mainly from two sources: the citations from the Confessions are supplemented by textual resonances and references in a marginal note to Jean Le Sueur's Histoire de l'église et de l'empire ${ }^{8}$ which he may well have used as a reader's guide to Augustine's spiritual autobiography. Ignoring the more mystical and reflective dimension of the Confessions-perhaps as a result of that hostility to 'mystiquerie' shared by many intellectuals at the end of the seventeenth century-Bayle adopts the moralistic tone of the Protestant Le Sueur, repeatedly emphasizing the moral weakness of his subject. While details of intellectual achievement and significant dates are provided, then, the disrespectful tone, later noted by Merlin and picked up by Voltaire, comes from the concentration on the young man's promiscuity and, in the second edition, his capacity for alcohol.9 Stylistically, the article, like Le Sueur's account before it, works on the reader's moral sense by its profusion of censorious terms: Saint Augustine "se plongea dans la débauche des femmes" and "s'abandonna aux instincts de cette furieuse passion." Not only that, his promiscuity was such an ingrained habit- "il contracta une si forte habitude d'incontinence"-that

${ }^{8}$ Jean Le Sueur, Histoire de l'église et de l'empire, 8 vols. (Geneve: Duillier, 1686-1687), 3:48492. This is the edition used by Bayle in "Augustin." Bayle's choice of Le Sueur is inspired by that author's use of the Confessions as his primary source-Bayle always selects secondary sources which respect primary material-and by the historian's refusal of hagiography.

$\theta$ Bayle, "Augustin," footnotes A, B, C and I; the latter is an addition to the second edition in 1702. The attribution of drunkenness to Augustine depends on a disputed translation of the word 'crapula'. 
even after his conversion and dismissal of his concubine, "il reprit le commerce d'impureté."10

This slightly obsessive note has two causes. On the one hand, it is inseparable from the moral rigorism informing many of the entries in the Dictionnaire. On the other, it is a stylistic device used repeatedly by Bayle, namely, the creation of caricature by telescoped accumulation of error or vice." In other words, despite its apparently antiseptic, factual presentation, the article-like so many others-has an ideological bias, which here works against its subject, imposing on Saint Augustine that raideur identified by Henri Bergson as one of the main causes of laughter. ${ }^{12}$ Iconoclastic in both intention and technique, the entry's comedy makes the reader an accomplice in its undermining of the moral authority of the sinner turned saint. Clues are given as to the reasons for this disrespect.

Bayle's short biography of Saint Augustine runs counter to his determination, stated in the preface to the first edition of the Dictionnaire (1697), to avoid unnecessary duplication of already existing compilations. Two abbreviated lives of the Saint were already in wide circulation: the first in volume one of Louis Moréri's Le Grand dictionnaire historique, the second in volume three of Louis-Ellies du Pin's widely acclaimed, if somewhat controversial, ecclesiastical history. Both authors, however, as Bayle observes, pass "trop légérement sur la vie déréglée de St. Augustin." Moreri, in fact, makes passing references to Augustine's dissipation of time earmarked for study and to "des affections déréglées qui faillirent le perdre," while du Pin's euphemistic allusions to "le desordre" and "les mauvaises inclinations" evident in the Saint's youth, yield momentarily to the more definite if elliptical reference to "la débauche" and "les feux de l'amour" described in the Confessions. ${ }^{13}$ In a word, inordinate respect for the Doctor of Hippo has led the two authors, both Roman Catholics, to conceal the Saint's unhappy past and to write not biography but hagiography. Bayle's reaction is not dissimilar from that of Adrien Baillet, a Roman Catholic critic also quoted in the article, who-like our author and so many others of his generation-espouses critical history in the contemporary conflict between histoire éloquente and histoire savante. Edification may be the assumed end of hagiography but it is more instructive, in Bayle's opinion, "de

so Bayle, "Augustin," in corp. and footnote B.

1 Whelan, The Anatomy, 6-25, 232-40.

12 Henri Bergson, Le rire, essai sur la signification du comique (Paris: Presses Universitaires de France, 1978), 7-22.

13 Louis Moréri, Le Grand dictionnaire historique, 2 vols., $3 \mathrm{~d}$. ed. (Lyon: Jean Girin \& Bar-

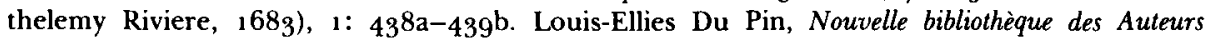
ecclesiastiques (vols. 1-3: Paris: André Pralard, 1686-1689; vols. 4-6: Mons: Huguetan, 16911692), 3: 505-82 1. Bayle, "Augustin," in corp. For a different attitude to Du Pin, cf. Whelan, The Anatomy, 26-5o. 
faire conoître les grans hommes à droit [sic] et à gauche."14 His reasons are clear. Hagiography, a religious form of panegyrics and a branch of eloquent history, is-given its neglect of sources, here the Confessions-a spurious history which may mislead and even corrupt its less informed readers. Once concealed, Augustine's sins cannot be censured and the unwary might follow a similarly immoral path to sanctity. The disrespect of the Dictionary entry has, therefore, a scholarly, even a didactic motivation: puritanism and caricature combine to create a counter-history. Now, while this generalization of the article's iconoclasm, together with the reappearance of its historical criticism some thirty years later in Barbeyrac's treatise, ${ }^{15}$ anticipate the Enlightened endeavor of the next generation, Bayle's self-conscious intellectual affiliations are with the critical enterprises of his own age, affiliations even more obvious in the theological concerns of the article.

Anticipating the shock the entry "Augustin" would cause, Bayle is careful to provide himself-in a cross-reference to the article on the Jesuit Jean Adam-with fellow iconoclasts, distinguished by their "rudes coups" against the Doctor of Hippo. ${ }^{16}$ In the entry "Adam," then, an ad hoc alliance is created with the Jesuit theologian, whose Molinist sympathies led him to question Augustine's theology of grace and to advance "des choses choquantes contre le même Saint Augustin."17 With evident approval, Bayle also notes Adam's hostility to the inflated position occupied by Augustine in the magisterium of the Roman church: "il vouloit bien que l'on sût qu'il ne tenoit pas Saint Augustin pour un bon modele de foi dans ces matieres." 18 Now, adds the author of the Dictionnaire, Adam is but one voice in a "grande nuée de témoins"-a cloud of witnesses which includes both the Arminians and the author of the Commentaire philosophique - who maintain that the Doctor of Hippo is not "la regle de la foi." 19 The choice of allies in this article is curious, given Bayle's

14 Adrien Baillet, Des Enfans devenus célébres par leurs Ėtudes ou par leurs Ecrits (Paris: Antoine Dezallier, 1688), 55-64. Bayle, "Augustin," in corp. For the debates concerning the place of eloquence in history, cf. Whelan, The Anatomy, $52-114$.

15 Barbeyrac, Traité, 12.

16 Bayle, "Adam, Jean," footnotes C, D and L. The cross-reference occurs at "Augustin” (e), and the quote comes from the text of that article.

17 Bayle, "Adam" (in corp) which expresses an attitude directly opposed to an earlier opinion in the Critique générale (1682). There (C.G., Let. XI, $\$ \mathrm{i}$ in Oeuvres diverses 4 vols. [The Hague: La Compagnie des Libraires, 1737], 4 vols, 2: 47 a) Bayle censures Adam for his critique of Augustine. This raises the important point of the ad hoc nature of Bayle's thought; an author cited as an ally on one occasion may be rejected as an enemy on another-one more reason to insist on a contextualization of Bayle's thought.

18 Bayle, "Adam", footnote C.

19 Bayle, 'Adam', footnote L: another example of an ad hoc alliance, this time with Leclerc, whose theology and critical positions vis à vis the Scripture Bayle repudiated (Elisabeth Labrousse, Pierre Bayle, vol. 2: Hétérodoxie et rigorisme (The Hague: Martinus Nijhoff, 1964), 328-31). 
Augustino-Calvinist leanings and his opposition to Jesuit and Arminian theologies of grace. ${ }^{20}$ Nonetheless, theological differences are ignored not as a result of a latent Pyrrhonism, but of an unequivocal sympathy with the Moderns in the "Querelle des Anciens et des Modernes." Like Le Clerc, whom he cites, like Barbeyrac and de Jaucourt whom he inspires, Bayle believes-to quote the Encyclopédie - that "on ne doit aucune déférence aveugle à quelque . . . autorité humaine que ce soit" and that the wisdom of the Ancients must not be allowed to stifle the curiosity, the research, and the opinions of modern theologians and scholars. ${ }^{21}$ Now, although this enlightened attitude to ecclesiastical tradition anticipates the Age of Reason, the author of the Dictionnaire's own inspiration is-paradoxically-firmly rooted in the theological past. The challenge to Saint Augustine's spiritual authority by Jesuits and Arminians is explicitly linked to the treatise on the Early Fathers by the Protestant minister and polemicist, Jean Daillé, one of Bayle's intellectual heroes. In his Traicté de l'employ des saincts peres (1632), Daillé tempers his profound respect for Augustine and the Fathers in general with a repudiation of their infallibility and a consequent refusal of their authority in matters pertaining to faith. ${ }^{22}$ The technique is similar in its recourse to source material, the iconoclasm more muted than that of the later Dictionnaire, but the unity of vision and theological presuppositions between the two Protestant authors is indubitable. The hostility to Saint Augustine and ecclesiastical tradition in the eighteenth century is the fruit, then, not of an earlier libertinism, but of the conflict between two traditions and two theologies. ${ }^{23}$ Geneva tackles Rome in that Bible of the Enlightenment, the Dictionnaire historique et critique.

The polemical thrust to the article "Augustin" is more, however, than an anachronistic echo of the commonplaces of seventeenth-century religious controversy. Acerbic disrespect in the Dictionary is frequently symptomatic of a deeper malaise, related to the traumas of the Revocation era. Here, the link with the Jesuit Adam and the reference to the Commentaire philosophique in that

2o Bayle's preference for the Augustino-Calvinist doctrine of grace is evident throughout his work. Nonetheless, his reading of natural law theorists and his admiration for certain key figures in Greek and Roman antiquity cause a shift in his thought ending in an ambiguous attitude to the role of grace in the moral life of the individual. See Whelan, The Anatomy, 52-81, 186-199.

"Encyclopédie, 12: $339 \mathrm{~b}$. The passage is a paraphrase of Barbeyrac (Traité, xii) and the sentiments are implicit in Bayle's historical practice. See Whelan, The Anatomy, 82-146.

${ }^{22}$ Jean Daillé, Traicté de l'employ des saincts Peres, pour le jugement des differends, qui sont aujourd'hui en la religion (Geneve: Pierre Aubert, 1632), 153. The reference occurs in Bayle, "Adam" (3o) and is one of many references to the treatise in the Dictionnaire. Thus, positions originally both polemical and Protestant pass through Bayle, Barbeyrac, and de Jaucourt-a liberal Protestant tradition-into the Enlightenment. The passage from the Reformation to the Age of Reason is facilitated by the gradual de-contextualization of theological positions which become increasingly more secularized as they pass from one thinker to the next.

23 Whelan, The Anatomy, 6-25, $116-46$. 
article provide clues to the political dimension of our entry. Bayle's Commentaire is in part a reaction to the Conformité de la conduite de l'église de France, pour ramener les protestants avec celle de l'église d'Affrique, pour ramener les donatistes à l'église catholique (1685), a translation of Saint Augustine's epistles to the Donatist bishops Vincent and Boniface by Philippe Goibaud du Bois, with a preface by the Archbishop of Paris, François de Harlay. Initially hostile to the use of constraint as a means of religious persuasion, Augustine later changed his mind, on seeing the impact of the imperial forces on the Donatists. The epistles appeal to Scripture and common sense in an attempt to justify and expound the Doctor of Hippo's new appreciation of the efficacy of political pressure in matters of conscience, and, given that the end is made to justify the means, its legitimacy. De Harlay's preface updates the arguments and, as the title implies, redirects the standard Roman Catholic defence of antiquity as a criterion of truth, ${ }^{24}$ to accommodate the contemporary use of force against the Huguenots. That is to say, persecution or, as de Harlay would have it, charitable and salvific violence is unquestionably right, given its historical and theological pedigree: "ce qui se fait presentement en France pour ramener les Protestans . . . n'est que ce que l'Eglise a fait en pareille occasion, dés qu'elle a été assez heureuse pour voir les Peres \& les Empereurs au nombre de ses enfans." 25 The third part of the Commentaire philosophique (1687) not only refutes the two Donatist epistles step by step, it also attempts to sabotage de Harlay's political application of antiquity by an iconoclasm directed, to quote Barbeyrac, against "le grand Patriarche des Persécuteurs Chrétiens." later Dictionnaire differs only in tone, precision, and erudition from the earlier work. In both, embracing Jean Adam as an ally and reapplying Daillé's methodology, Bayle subverts the triumphalism of Rome and her justification of persecution via Saint Augustine by revealing the intellectual fickleness, polemical exaggerations, volatile temperament, and early promiscuity of the Doctor of Hippo-surely an unreliable guide in the matter of civil and religious toleration. The indignation and the arguments reappear obsessively in the eighteenth century, but they carry little of the acerbity of the Dictionary entry. The article "Augustin" was written some ten years after the Revocation, against a background of persecution and the acknowledged impotence of the Commentaire philosophique, whose ideas were in advance of its time. The carica-

$2_{4}$ The Conformité was printed in Paris by Jean Baptiste Coignard, 1685 . For the use of antiquity as a criterion of truth see Walter Rex, Essays on Pierre Bayle and Religious Controversy (The Hague: Martinus Nijhoff, 1965), 3-74. The intellectual, political, and historical background to this pamphlet is considered by Elisabeth Labrousse, "Une Foi, une loi, un roi?": la Révocation de l'Edit de Nantes (Genève: Labor et Fides and Paris: Payot, 1985), $102-105$.

25 Conformité, iii-iv.

26Barbeyrac, Traité, $3^{04}$ and Bayle, Commentaire philosophique, III (Oeuvres diverses, 2: 445a-b). 
ture and attack on Saint Augustine's authority stem from the bitterness and frustration of a Huguenot who matched his pen against the sword, only to witness the triumph of the sword, upheld by the moral authority of a Father of the Church. In a sense, then, the article "Augustin" is a last-ditch stand, a final protest against the sanctification of constraint of conscience at the close of the grand sì̀cle.

To the bewilderment of the modern critic, however, the iconoclasm of the entry is subverted from within by what can only be termed a double-think on Bayle's part: the sinner and persecutor becomes the patron saint of Protestantism. Abandoning the alliance with the Jesuits, our author now associates with the Jansenists, embraced-like his fellow Calvinists-as the "défenseurs de Saint Augustin." 7 The argument has two stages. Firstly, years of acrimonious controversy are brushed aside as Bayle maintains that Augustine and Jansenius' doctrines of grace "sont une seule et même doctrine." Secondly, in condemning Calvin's theology of grace, the Council of Trent, he continues, "a nécessairement condamné celle de Saint Augustin." The association between Augustine, Calvin, and Jansenius - to the detriment of Roman Catholicism, thereby deprived of Augustine's authority in these matters-is neither original to Bayle nor novel in his thought. Initiated as a polemical tool by the enemies of Port-Royal, the confraternity is quickly annexed to the defence of Protestantism, for it challenges Catholic claims both to infallibility and perpetuity of credence. Such is its purpose in the article "Augustin." Quoting Jacques Basnage, the Huguenot ecclesiastical historian, and thrusting at Bossuet's Histoire des variations des églises protestantes (1688), Bayle concludes that the Roman pretension "d'avoir la foi de Saint Augustin \& de n'avoir jamais varié dans la doctrine," given the pronouncements of the Council of Trent, is no more than a political ploy "pour garder le decorum, \& pour éviter la dissipation du Systême qu'un aveu de la vérité produit nécessairement." ${ }^{28}$ Now, these theological abstractions, once read within the context of both Bayle's entire literary output and the religious controversy of the Revocation era, achieve a more immediate political significance. The application of Augustine's Donatist epistles to the Protestants depends on a transformation of the charge of heresy into one of schism. The transformation was effected, prior to the

27 Bayle, "Augustin," footnote F and Whelan, The Anatomy, 40-44. For the polemical use of this term, see Nigel Abercrombie, Saint Augustine and French Classical Thought (Oxford: The Clarendon Press, 1938), 4.

28 Bayle, "Augustin," footnote F. The argument follows Basnage's reversal of Bossuet's argument in the Histoire des variations, namely that "(les) variations (sont) une marque de fausseté" (Oeuvres 43 vols. [Versailles: J. A. Lebel, 1815-1819], 16: 4). Basnage, firstly in the Histoire de la religion des eglises réformées, 2 vols. (Rotterdam: Abraham Acher, 16go), 2: 452ff, and at greater length in the Histoire de l'église, 2 vols. (Rotterdam: Reinier Leers, 1699. passim), demonstrates the falsity of the Roman church by establishing the variations in her doctrines of grace. 
Revocation, by a minimalist interpretation of doctrinal differences and the contention that Calvinist heresies were the result, not the cause, of schism. ${ }^{29}$ To argue, as Bayle does here and elsewhere, that Rome, despite her protestations to the contrary, has abandoned Augustine, is to reverse the charge of schism: Geneva and Port-Royal together maintain a doctrinal tradition, persecuted by the post-Tridentine church. The charge is re-inforced by the cavalier annexation of Jansenism to Calvinism. Ten years after the Revocation, the position adopted here looks back in indignation, even in pain, posing allusively the question put in a similar context by Jacques Basnage: "De quoy servent les anathemes des Papes, si lors méme qu'ils ont condamné la doctrine de Jansenius on ne laisse pas de demeurer dans sa communion \& de la defendre?"so The question highlights the injustice of the recent fortunes of the Huguenots who, as defenders of the Doctor of Hippo-unlike their reluctant allies, the Jansenists-were forced to leave both church and state by a politico-religious institution, which exercises an arbitrary, totalitarian power. Thus, an article which, at first sight, seems to justify the interpretation of Bayle as an ideological Proteus, friend to libertines and poisoner of minds, once placed back in its socio-historical context, echoes through the centuries in Protestant tones. Eighteenth-century authors are not to be blamed, however, for their insensitivity to the Calvinist affiliations of the article. Bayle himself generalizes his target, in a manner reminiscent of the polemical style of the libertines, to include contemporary Protestantism.

The bitter dispute which broke out after the publication of the Commentaire philosophique between Bayle and Jurieu over political and toleration theories is echoed in the article in the form of a derogatory reversal of Jurieu's selfproclaimed orthodoxy. Bayle's defence of political absolutism and of civil and religious toleration earned him a reputation as a traitor and a Socinian and, thanks to Jurieu's efforts, his Commentaire figures prominently in the condemnation of certain "erreurs capitales" by the Synod of the Walloon Churches, held in Amsterdam in August 169o.31 The seventh proposition condemnedaccording to Jurieu's Le Tableau du socinianisme (169o), quoted by Bayleconcerns the role of the secular powers in religious matters. The Synod decried as "false, scandalous and pernicious" the assertion "Que le Magistrat n'est point en droit, d'employer son Autorité, pour abattre l'Idolatrie, \& empêcher les progrés de l'Heresie." ${ }^{22}$ In other words, as Bayle delights in observing, Jurieu and his associates have joined hands with the persecutors of

\footnotetext{
29 Labrousse, Une foi, 95-112.

3o Basnage, Histoire de la religion des églises réformées, 2: 507 .

3 Pierre, Jurieu, Le Tableau de socinianisme (The Hague: Abraham Troyel, 1690 ), 56off.

32 idem, 566 and Bayle, "Augustin," footnote $\mathrm{H}$.
} 
the Huguenots. Not only did Saint Augustine embrace a similar position, but "le Clergé de France" also used the Saint's authority and similar arguments "pour justifier la conduite de la Cour envers les Réformez."33

It is not Bayle and the moderates, then, but Jurieu and the zealots, to use Guy Howard Dodge's terms, ${ }^{34}$ who are proven traitors of the Protestant cause. Insult is added to injury by the opposition, suggested earlier in the footnote, between the partnership Augustine-Jurieu and Jean Claude, a minister and controversist, nicknamed "l'Empereur Claude" as a result of his prestige and moral authority among the Huguenots. Had Claude lived a little longer, observes Bayle, "il eut été censuré d'avoir censuré St. Augustin." For, unlike Jurieu, "M. Claude a trouvé mauvais que St. Augustin ait aprouvé les lois pénales contre les Hérétiques," a fact which isolates both Jurieu and the Walloon Synod at Amsterdam from, to coin a phrase, "the moral magisterium" of their own church. Not only does Jurieu's position, according to Bayle, represent a shift in the Reformed attitude to constraint in religious matters, it also highlights a volte face in the minister's own thinking. His somewhat ambivalent critique of persecution in his early works yields after the Revocation to a defense of enforced religious uniformity by the civil powers, under certain conditions. 35

This change "du blanc au noir" creates a further link between the theologian of Rotterdam and the Doctor of Hippo. Both changed their minds and, adds Bayle with a touch of malice, for similar reasons of political opportunism. The imminent destruction threatening European Catholicism, prohesied by Jurieu, depended on a Protestant conspiracy to effect its downfall, $3^{6}$ hence the minister's new appreciation of the role of political powers in religious affairs. Prophecy here, as throughout the Dictionnaire, is perceived as a tool of politics and violence as the instrument of totalitarian orthodoxy, whether the Janus-face of orthodoxy be Roman or Reformed. The sabotage of Augustine and Jurieu's spiritual authority is, in fact, a repudiation of theological and political theories wherein might creates right. The analysis is libertine in its perceptions of the politicization of religion but, for all its anticipation of the Enlightenment, 37 it

39 Bayle, "Augustin," footnote $\mathbf{H}$.

34 Guy Howard Dodge, The Political Theory of the Huguenots of the Dispersion (New York: Columbia University Press, 1947), $94 \mathrm{ff}$.

35 idem, 163-197 and Bracken, Harry M., Mind and Language, Essays on Descartes and Chomsky (Dordrecht: Foris Publications, 1984), 83-96.

${ }^{36}$ Bayle is here using Gédéon Huet, Apologie pour les vrais tolérans (Dordrecht: Theodore Goris, 169o), 133-34. Cf. Dodge, The Political Theory, $224 \mathrm{ff}$.

37 For example, the article "Prêtres" in the Encyclopédie. The notion of the politicization of religion was earlier popularized by Gabriel Naudé, Science des princes, ou considerations politiques sur les coups d'état (1639), read by Bayle and frequently used by him, with or without citation. 
looks back to the traumas of the Revocation and Bayle's tragic involvement in the history of his own time.

To conclude: the article "Augustin," like so many of the neglected historical articles in the Dictionnaire, calls for a reassessment of some of the established critical positions on Bayle. Firstly, it raises a methodological issue similar to that raised in 1932 by Ernst Cassirer who, repudiating the "chronological," "lengthwise" consideration of Enlightenment thinkers, called instead for a study of eighteenth-century philosophy in action and "in the constantly evolving process of thought." ${ }^{8}$ As our brief analysis has demonstrated, the "lengthwise" consideration of Bayle as merely a precursor of the Enlightenment-for all its truth-falsifies the mischievous understatement, the subtle polemic and the historico-political significance of his work. Moreover, Bayle, like his model Montaigne, is an author whose thought is reactive, evolving, multi-faceted, thought which also needs to be considered in terms of its sources and evolution. Citation functions as a kind of shorthand for Bayle and his well-read contemporaries, who shared his mental universe. In the twentieth century, this instinctive comprehension of the way a source is being used or abused, absorbed or partially rejected must be replaced by a painstaking reconstruction of the intellectual map of the Dictionnaire and the dynamics of the reception of its sources. Stripped of the anachronisms and misconceptions resulting from eighteenth-century interpretations, Bayle's thought will then appear, with all its ambiguities and allusiveness, as an intellectual commitment to a somewhat old-fashioned, perhaps even mythical Calvinism, held in tension with philosophical eccentricities, humanitarian and scholarly ideals.

Secondly, the polemical nature of the entry "Augustin" challenges the notion that Bayle abandons in the Dictionnaire his earlier recourse to religious history as an apologetic, embracing instead the pursuit of historical exactitude.39 As our demonstration illustrates, the scrupulous citation of sources, the concern to set the historical record straight, is inseparable in Bayle's practice of history from a provocative iconoclasm, subversive in its determination to bring ideological and perhaps political liberation through the medium of laughter. Now, polemics and history, according to some historiographers, are mutually exclusive, a contention echoed by Bayle in his life-long critique of court historians and the historical propaganda of his own and other ages.

Three aspects of the short biography of Augustine, however, distinguish

\footnotetext{
${ }^{8}$ Ernst Cassirer, The Philosophy of the Enlightenment, trans. Fritz C. A. Koelln and James P. Pettegrove (Boston: Beacon Press, 1966), viii; also Elisabeth Labrousse, Bayle, Past Masters (Oxford/New York: Oxford University Press, 1983 ), 11-12, 88, and 90 .

39 Elisabeth Israels Perry, From Theology to History: French Religious Controversy and the Revocation of the Edict of Nantes (The Hague: Martinus Nijhoff, 1973), 200.
} 
the article and all those like it from the activity of the propagandist. In the first place, Bayle alerts the reader, as we have seen, to the distortional intention of the entry. The rejection of totalitarian politics is accompanied by the repudiation of totalitarian history, here hagiography, which attempts to whitewash the instigators of persecution. In the second place, influenced by Pascal's Provinciales, a model of satirical writing for ensuing generations, Bayle uses scrupulous citation of the Confessions-as Pascal had used the writings of the Jesuitsto condemn error from its own mouth. In the third place, and here the link with Baillet is important, scrupulous quotation is symbolic of confidence in the liberating effect of scholarship and of respect for the reader, whose judgment, according to the 'Modernes', is to be informed, not brow-beaten into consent. Laughter may be annexed to the cause but, like Pascal before him, Bayle distinguishes "entre rire de la religion" and ridicule of "les faussetés (de) l'esprit de l'homme." $4^{\circ}$ It is only in the next generation, then, that an essentially anti-Catholic historiography will be transformed into an anti-Christian polemic, thereby destroying the mental universe from which it springs.

Trinity College, Dublin

$4^{\circ}$ Pascal, Les Provinciales, edited by Louis Cognet, (Paris: Garnier Frères, 1983), Lettre XI, 195 and The Anatomy, 232-4o. 